\title{
Identification of a novel KCNQI mutation associated with both Jervell and Lange-Nielsen and Romano-Ward forms of long QT syndrome in a Chinese family
}

\author{
Su Zhang ${ }^{\dagger 1,2}$, Ke Yin ${ }^{\dagger 1}$, Xiang Ren ${ }^{1}$, Pengyun Wang1, Shirong Zhang1, \\ Lingling Cheng1,2, Junguo Yang ${ }^{1,3}$, Jing Yu Liu ${ }^{1}$, Mugen Liu*1 and \\ Qing Kenneth Wang*1,4
}

\begin{abstract}
Address: ${ }^{1}$ Key Laboratory of Molecular Biophysics of Ministry of Education, College of Life Science and Technology, Center for Human Genome Research, Huazhong University of Science and Technology, Wuhan, P. R. China, ${ }^{2}$ Hubei Vocational Technical College, Xiaogan, Hubei, P. R. China, ${ }^{3}$ Department of Cardiology, Union Hospital, Huazhong University of Science and Technology, Wuhan, P. R. China and ${ }^{4}$ Center for Cardiovascular Genetics, Department of Molecular Cardiology, Lerner Research Institute, Cleveland Clinic, and Department of Molecular Medicine, Cleveland Clinic Lerner College of Medicine of Case Western Reserve University, Cleveland, Ohio, USA

Email: Su Zhang - zhangsuhealth@126.com; Ke Yin - ayyk19821130@gmail.com; Xiang Ren - renxiang@mail.hust.edu.cn; Pengyun Wang - wpy0110@126.com; Shirong Zhang - shirley4444@gmail.com; Lingling Cheng - xgcyh@sohu.com; Junguo Yang - yjg.email@yahoo.com.cn; Jing Yu Liu - liujy@mail.hust.edu.cn; Mugen Liu* - lium@mail.hust.edu.cn; Qing Kenneth Wang* - qkwang@mail.hust.edu.cn

* Corresponding authors †Equal contributors
\end{abstract}

Published: 9 April 2008

BMC Medical Genetics 2008, 9:24 doi:10.1 186/147I-2350-9-24
Received: 21 November 2007

Accepted: 9 April 2008

This article is available from: http://www.biomedcentral.com/I47I-2350/9/24

(C) 2008 Zhang et al; licensee BioMed Central Ltd.

This is an Open Access article distributed under the terms of the Creative Commons Attribution License (http://creativecommons.org/licenses/by/2.0), which permits unrestricted use, distribution, and reproduction in any medium, provided the original work is properly cited.

\begin{abstract}
Background: Long QT syndrome (LQTS) is a cardiac disorder characterized by prolonged QT intervals on electrocardiograms (ECG), ventricular arrhythmias, and sudden death. Clinically, two inherited forms of LQTS have been defined: autosomal dominant LQTS or Romano-Ward syndrome (RWS) not associated with deafness and autosomal recessive LQTS or Jervell and Lange-Nielsen syndrome (JLNS) associated with deafness.

Methods: A Chinese family with both RWS and JLNS was identified. Family members were diagnosed based on the presence of a prolonged QT interval as seen on a I2-lead ECG and a medical history of syncope, palpitation, and deafness. Mutational studies in the KCNQI potassium channel gene were performed using direct DNA sequence analysis and restriction length polymorphism analysis.

Results: The proband in the Chinese family and her brother had previously been diagnosed with JLNS, and two other members were affected with RWS. The proband was also affected with atrial fibrillation. A single nucleotide substitution of $C$ to $T$ at nucleotide 965 of KCNQI was identified, and the mutation resulted in the substitution of a threonine residue at codon 322 by a methionine residue (T322M). The novel heterozygous T322M mutation was identified in two patients with RWS, one member with borderline QTc, and two normal family members. The two JLNS patients in the family carried the homozygous T322M mutation. The T322M mutation was not found in 200 Chinese normal controls.

Conclusion: Our results suggest that T322M is a novel mutation that caused RWS with high intrafamilial variability in the heterozygous carriers and typical JLNS in the homozygous carriers within this Chinese family. The T322M mutation is the first mutation identified for JLNS in the Chinese population.
\end{abstract}




\section{Background}

Long QT syndrome (LQTS) is a disorder of cardiac repolarization characterized by prolonged QT intervals and abnormal $\mathrm{T}$ waves on surface electrocardiograms (ECG), torsade de pointes, and sudden death [1-3]. Two forms of inherited LQTS have been described: Romano-Ward syndrome (RWS), which is an autosomal dominant form of LQTS without sensorineural deafness, and Jervell and Lange-Nielsen syndrome (JLNS), which is an autosomal recessive form of LQTS associated with deafness [4-6].

RWS is the most common form of inherited LQTS [7]. More than nine genes have been identified for RWS:KCNQ1 (or KvLQT1, LQT1) [8] on chromosome 11p15.5, KCNH2 (or HERG, LQT2) on chromosome 7q35-36 [9], SCN5A (LQT3) on chromosome 3p21 [10,11], Ankyrin-B (LQT4) on chromosome 4q25-27 [12], KCNE1 (LQT5) on chromosome 21q22 [13,14], KCNE2 (LQT6) on chromosome 21q22 [15], KCNJ2 (LQT7) 17q23.1 [16], CACNA1C (LQT8) on chromosome 12 p13.3 [17], and CAV3 (LQT9) on chromosome 3p25 [18]. Carriers with mutations in KCNJ2 and CACNA1C exhibit not only the LQTS phenotype but other phenotypes as well (designated as Andersen syndrome and Timothy syndrome, respectively) $[16,17]$.

JLNS is a rare autosomal recessive disorder that appears to have a worse prognosis than RWS [19]. JLNS can be caused by homozygous or compound heterozygous mutations in either KCNQ1 or KCNE1 [13,20-27]. KCNQ1 encodes a potassium channel gene with six transmembrane domains and forms functional $\mathrm{I}_{\mathrm{Ks}}$ potassium channels by assembling with minK (encoded by KCNE1) in the heart $[8,28]$.

In this report, we identified a novel mutation in the KCNQ1 gene that simultaneously caused RWS and JLNS within a Chinese family. The results expand the spectrum of KCNQ1 mutations causing RWS and JLNS.

\section{Results}

One three-generation JLN/RWS family was identified in China and clinically evaluated. The pedigree structure of the family is shown in Figure 1, and clinical characteristics for family members are listed in Table 1 . The proband (patient III:1) had been deaf since birth. At 3 years of age, she was referred for detailed examinations due to syncope. Since then, she has experienced 11 additional syncopal episodes, most of which were preceded by exercise and sport. Current ECG analysis revealed a markedly prolonged QTc ranging from 0.520 to 0.608 s (a representative ECG is shown in Figure 2). She was then diagnosed as having JLNS (deafness + LQTS). Interestingly, the proband was also affected with atrial fibrillation. The proband's brother (patient III:2, Figure 1) was also affected with deafness and LQTS (JLNS). His QTc ranged from $0.512 \mathrm{~s}$ to $0.627 \mathrm{~s}$, and he had experienced three syncopal episodes in the past triggered by exercise and sport. Their parents had normal hearing and normal ECGs with a QTc of $0.42 \mathrm{~s}$ (father) and $0.43 \mathrm{~s}$ (mother). Individual II: 1 had experienced one syncopal episode triggered by exercise when she was 20 years old. No syncope was identified for individual II:2, but he had experienced palpitation and dyspnea. The parents' marriage was not consanguineous.

Further analysis of other family members identified two other members affected with RWS. Individual II:4 was clinically diagnosed with LQTS because she had a moderately prolonged QTc of $0.455 \mathrm{~s}$ and a medical history of dyspnea and palpitation. Her mother (I:2, Figure 1) was also affected with LQTS with a prolonged QTC of $0.487 \mathrm{~s}$. Both I:2 and II:4 had normal hearing. Individual III:4 was a male with a borderline QTc of $0.447 \mathrm{~s}$. No stress testing was performed for III:4 or other family members. Individuals I:1, II:3, and III:3 had a normal QTc of 0.420 s, 0.400 s, and $0.397 \mathrm{~s}$, respectively.

A homozygous $\mathrm{C} \rightarrow \mathrm{T}$ transition was identified at nucleotide 965 in exon 7 of KCNQ1 in the DNA sample from the proband (Figure 3 ). The $\mathrm{C}$ to $\mathrm{T}$ change resulted in the

Table I: Genotype-phenotype correlation in the Chinese family with both RWS and JLNS and KCNQI mutation T322M

\begin{tabular}{|c|c|c|c|c|c|}
\hline ID & Sex/Age & Deafness & Symptoms & QTc (s) & Genotype \\
\hline $\mathrm{I}: \mathrm{I}$ & $M / 7 I$ & No & None & 0.420 & T322 Т322 \\
\hline $1: 2$ & $\mathrm{~F} / 65$ & No & Chest discomfort & 0.487 & T322 M322 \\
\hline II:I & $\mathrm{F} / 42$ & No & I syncope (trigger, exercise) & 0.430 & T322 M322 \\
\hline$\|: 2$ & $M / 43$ & No & Palpitation, dyspnea & 0.4200 .4100 .400 & T322 M322 \\
\hline$\| 113$ & $\mathrm{~F} / 39$ & No & None & 0.400 & T322 T322 \\
\hline II:4 & $F / 36$ & No & dyspnea, palpitation & 0.4550 .4540 .444 & T322 M322 \\
\hline III: I & F/I7 & Yes & 12 syncope (trigger, exercise) Atrial fibrillation & 0.5200 .608 & M322 M322 \\
\hline III:2 & $M / 8$ & Yes & 3 syncope (trigger, exercise) & 0.5120 .627 & M322 M322 \\
\hline III:3 & $M / 16$ & No & None & 0.397 & T322 T322 \\
\hline III:4 & $M / 9$ & No & None & 0.447 & T322 M322 \\
\hline
\end{tabular}




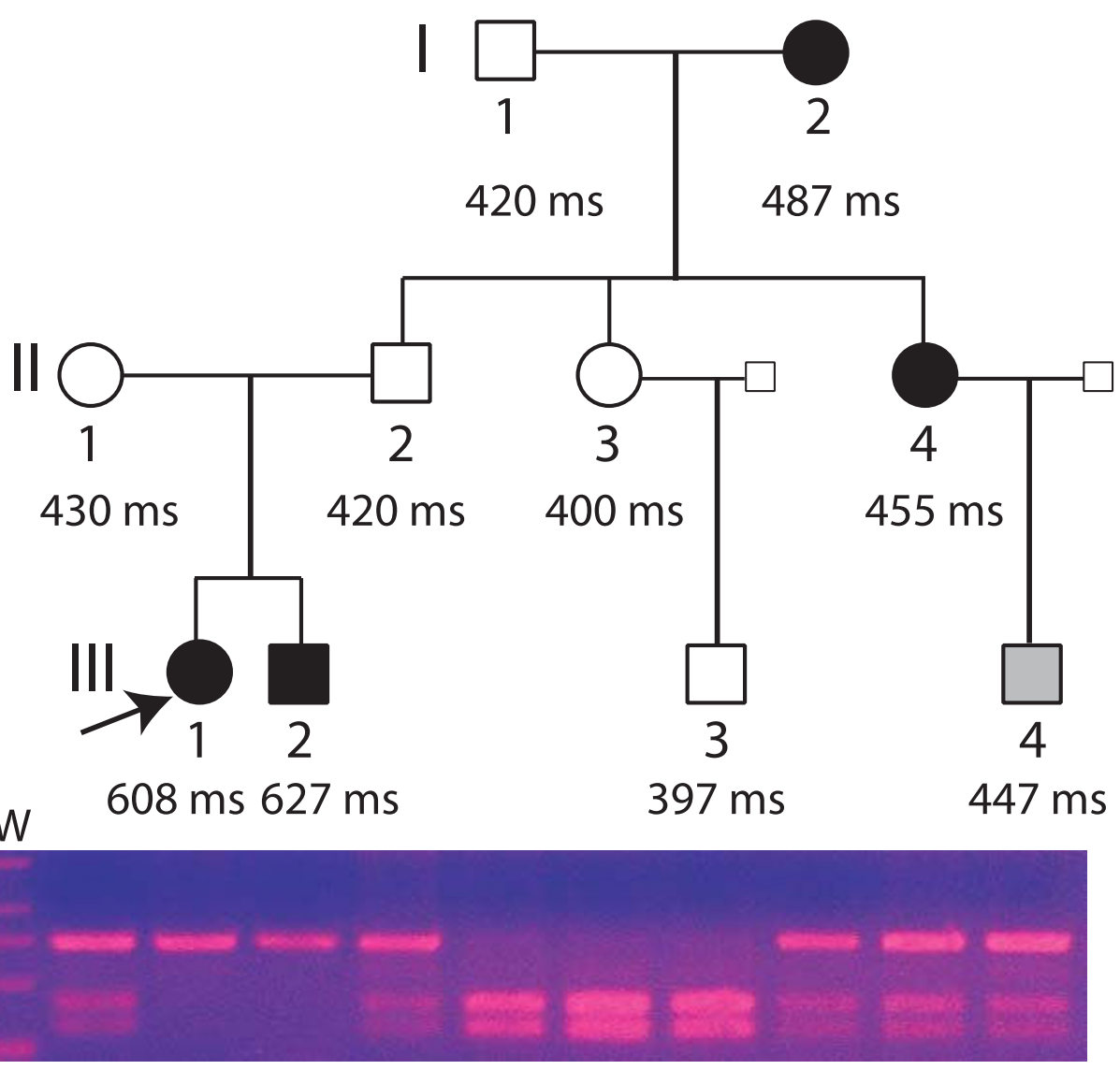

\section{Figure I}

Pedigree structure of the Chinese family with JLNS and RWS. The results of RFLP analysis for mutation T322M are shown below each symbol. Affected male III:I and females I:2 and III:2 are indicated with filled squares and circles; normal members are indicated with open symbols; individual III:4 with borderline QTc is shown with a gray symbol. QTc for family members is shown below each symbol as ms. The three-generation family is notable for the proband (III:I, indicated by an arrow) and her brother (III:2), who were affected with deafness and had a severely prolonged QTc.

substitution of a threonine residue by a methionine residue at codon 322 (T322M) (Figure 3). The homozygous T322M mutation was also identified in the proband's brother (individual III:2, Figure 1). The parents and family members II:4 and I:2 were heterozygous for the mutation.

The detection of mutation T322M was further confirmed by RFLP analysis showing the presence of only the mutant allele (M322) in the proband and her brother (Figure 1, Table 1). RFLP analysis also demonstrated that family members II:1, II:2, I:2, II:4, and III:4 were heterozygous for the mutation (T322 and M322) and that normal individuals I:1, II:3, and III:3 carried the wild type T322 allele. The M322 allele was not identified in 200 normal Chinese Han nationality controls (data not shown).

\section{Discussion}

In this report, we describe a Chinese family in which a heterozygous mutation in KCNQ1, T322M, resulted in RWS whereas the homozygous mutation resulted in JLNS associated with LQTS and deafness. Heterozygous mutations in the KCNQ1 gene have been reported in Chinese patients with RWS, but no KCNQ1 mutation associated with JLN has been reported in the Chinese population [29]. Thus, the T322M is the first KCNQ1 mutation identified for JLN in the Chinese population.

The penetrance of the phenotype in the family members with homozygous T322M was complete. The two homozygous mutation carriers, III:1 and III:2 (Figure 1), had a markedly prolonged QTc of up to $0.608 \mathrm{~s}$ and 0.627 $\mathrm{s}$, respectively, and both had experienced multiple syncopal episodes triggered by exercise and sport. These results are consistent with the finding by Schwartz et al. [24] that 


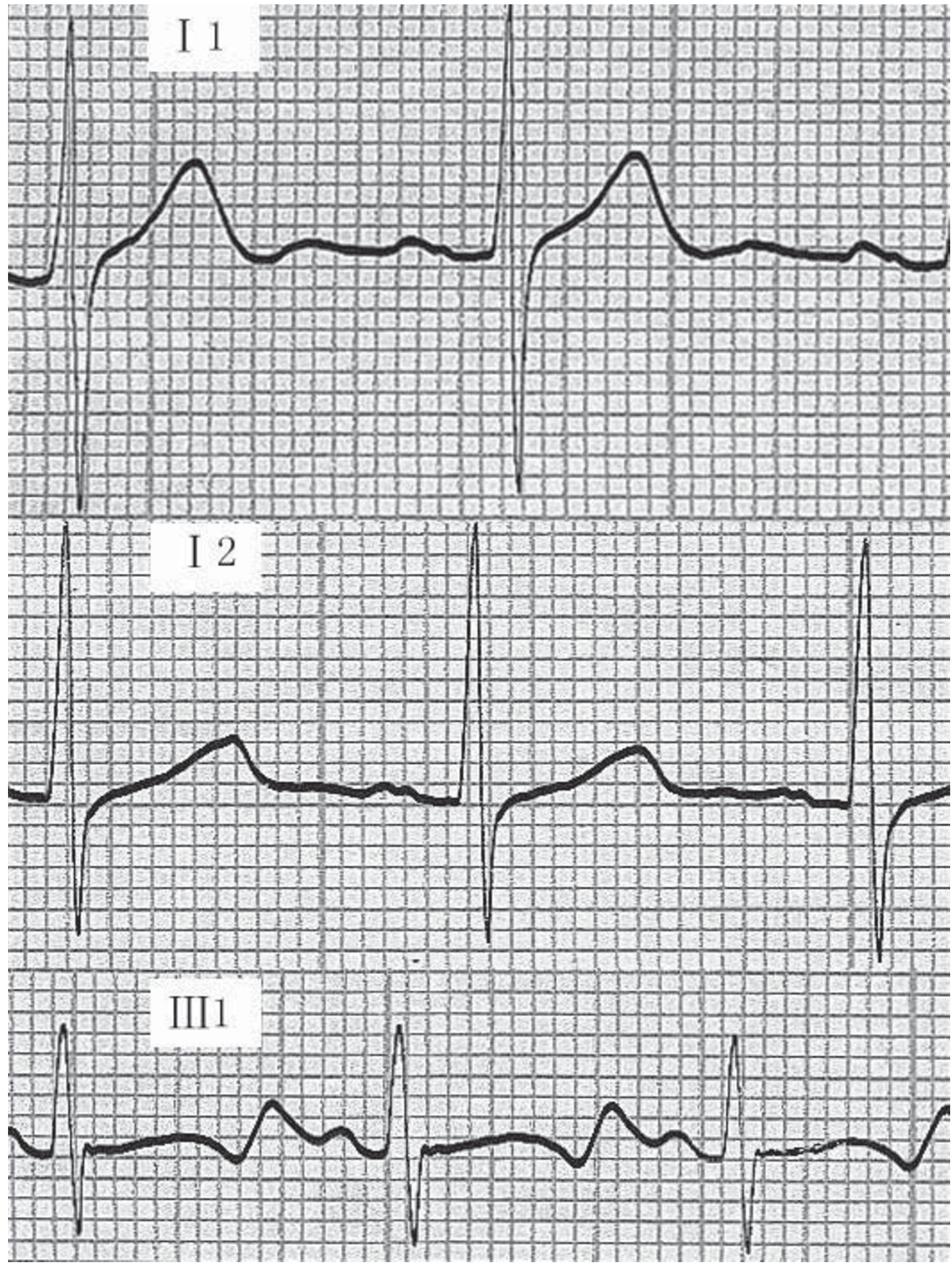

Figure 2

Representative electrocardiograms (ECG) from members of the Chinese family with LQTS. Top, ECG from a normal family member (I-I); Middle, ECG from a heterozygous mutation carrier; Bottom, ECG from a homozygous mutation carrier. 

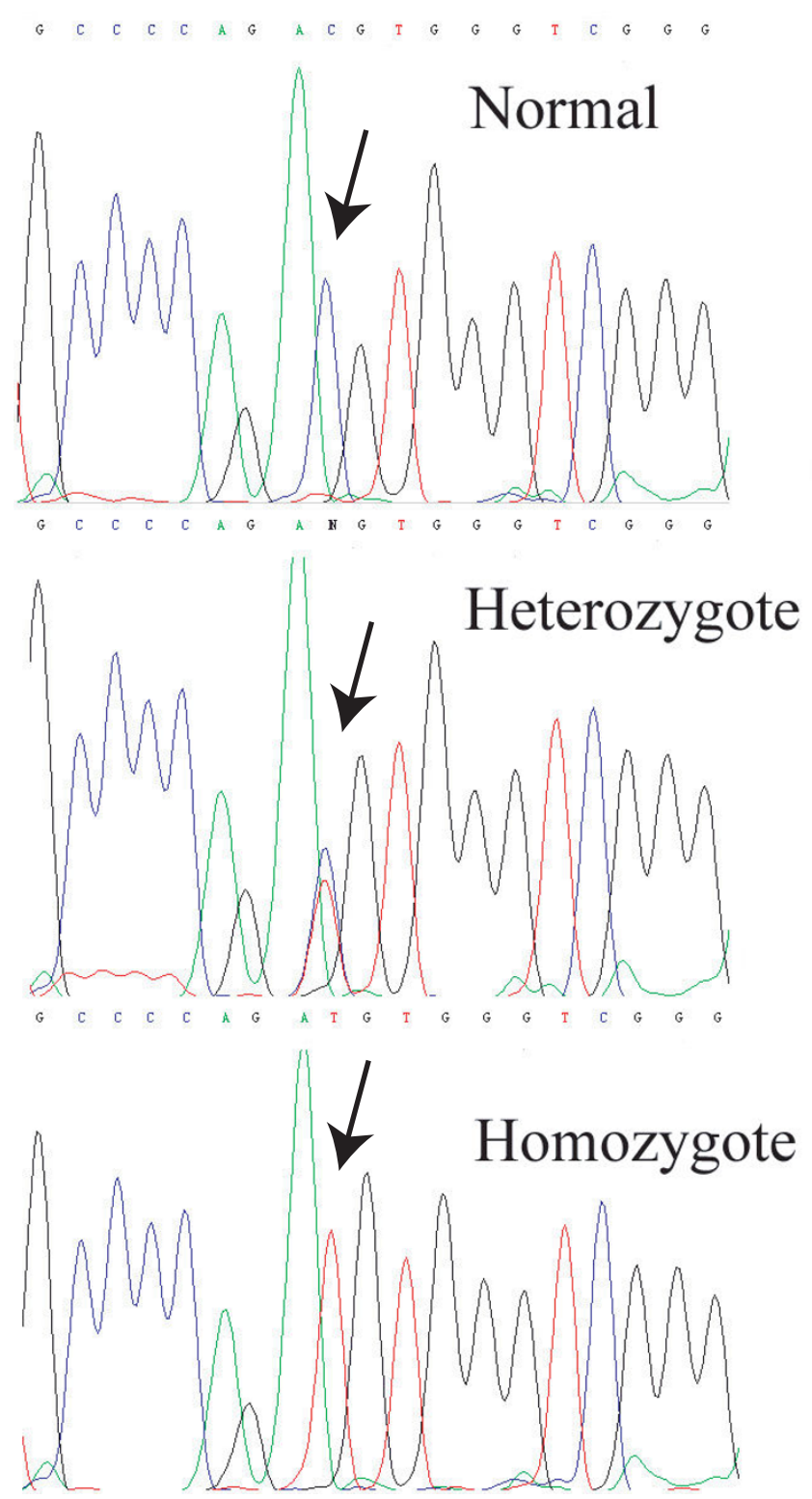

\section{Figure 3}

Identification of KCNQI mutation T322M ( $T$ to $C$ substitution at nucleotide 965). Top, normal sequence; Middle, heterozygous T322M mutation with both $\mathrm{T}$ and $\mathrm{C}$ at nucleotide 965; Bottom, homozygous T322M mutation.

JLN is a more severe variant of LQTS than RWS. Interestingly, individual III: 1 was affected by both LQTS and atrial fibrillation. Previously, in a Chinese family with atrial fibrillation and KCNQ1 mutation S140G, multiple family members had both LQTS and atrial fibrillation [30]. Further studies are needed to determine whether and how the T322M mutation is associated with atrial fibrillation.
The penetrance of the phenotype of QTc prolongation in heterozygous mutation carriers was not complete. Two carriers, II-1 and II-2, had a normal QTc (Table 1, Figure 1). On the other hand, two carriers, I-2 and II:4, were affected with RWS. The other carrier, III-4, had borderline QTc prolongation. The molecular mechanism that is responsible for the intra-familial variability or variable penetrance of the LQTS phenotype in heterozygous carriers is not clear, but environmental factors and modifying genes are likely possibilities.

\section{Conclusion}

This study identified a novel mutation, T322M, in the KCNQ1 gene that caused RWS with high intrafamilial variability in the heterozygous carriers and typical JLNS in the homozygous carriers within a Chinese family. To the best of our knowledge, T322M is the first mutation identified for JLNS in the Chinese population.

\section{Methods}

Study subjects, clinical diagnosis, and isolation of human genomic DNA

The LQTS family was identified in the Henan Province of China. Informed consent was obtained from all the participants or their guardians. This study complied with the Helsinki Declaration and was approved by the ethics committee of Huazhong University of Science and Technology.

LQTS was diagnosed based on the presence of prolonged QT intervals as seen on a 12-lead ECG and a medical history of syncope, dyspnea, and palpitation. The QT interval was manually measured, and the QTc was calculated using Bazett's formula for heart rate correction [31]. The diagnosis of LQTS was based on the work of Schwartz et al. [32] and others [8,10,11]. Asymptomatic individuals with a QTc of $\geq 0.47 \mathrm{~s}$ and symptomatic individuals (syncope, dyspnea, palpitation) with a QTc $\geq 0.45$ s were diagnosed with LQTS. Males with a QTc of $<0.44 \mathrm{~s}$ and females with a QTc of $<0.45$ s were considered normal. All others were diagnosed as having borderline QTc.

Peripheral blood was collected from the participants, and their total human genomic DNA was isolated using the DNA Isolation Kit for Mammalian Blood (Roche Diagnostic Co., Indianapolis, IN).

\section{Mutational analyses}

Mutation screening was performed using direct DNA sequence analysis. The exons and exon-intorn boundaries of the KCNQ1 gene were amplified with polymerase chain reaction (PCR). PCR was performed in a $25-\mu \mathrm{L}$ volume containing $50 \mathrm{mmol} / \mathrm{L} \mathrm{KCl,} 10 \mathrm{mmol} / \mathrm{L}$ Tris-HCl, $\mathrm{pH} 8.3$, $1.5 \mathrm{mmol} / \mathrm{L} \mathrm{MgCl}_{2}, 0.2 \mathrm{mmol} / \mathrm{L}$ of each dNTP, $0.5 \mu \mathrm{mol} /$ L of each primer, 1 U of Taq polymerase (TaKaRa Biotech- 
nology Co.), and 50 ng of genomic DNA. The amplification program consisted of one cycle of denaturation at $94^{\circ} \mathrm{C}$ for 3 min, 35 cycles of $94^{\circ} \mathrm{C}$ for $30 \mathrm{~s}, 50^{\circ} \mathrm{C}$ to $60^{\circ} \mathrm{C}$ for $30 \mathrm{~s}$ (with different annealing temperatures for different primer pairs), $72^{\circ} \mathrm{C}$ for $1 \mathrm{~min}$, and one cycle of extension at $72{ }^{\circ} \mathrm{C}$ for $7 \mathrm{~min}$. Each PCR product was separated by a $1.5 \%$ agarose gel, purified using the QIAquick Gel Extraction Kit (Qiagen Inc., Valencia, CA) and sequenced with the forward and reverse primers using the BigDye Terminator Cycle Sequencing v3.1 kit (Applied Biosystems, Inc.).

Mutation designation was based on the CDNA sequence for KCNQ1 transcript variant 1 (Genbank accession No. NM 000218).

Mutation T322M disrupted a MaeI restriction site, which allowed the restriction fragment length polymorphism (RFLP) analysis to confirm the mutation in family members and to test whether the mutation was present in the controls. Using PCR, we amplified exon 7 of KCNQ1, which contained the T322M mutation from all members of the family as well as 200 unrelated healthy Chinese individuals of Han nationality. The PCR product was 291 bp in length and the primers were 5'-AGAGTGGTGGGTTTGGGTTAG-3' (forward primer) and 5'-GAACGTAAGTGGGTCTGCTCA-3' (reverse primer). The PCR product was digested by two units of MaeI at $65^{\circ} \mathrm{C}$ overnight and separated on a $2.5 \%$ agarose gel.

\section{Abbreviations}

LQTS, long QT syndrome; RWS, Romano-Ward syndrome (autosomal dominant LQTS); JLNS, Jervell and LangeNielsen syndrome (autosomal recessive LQTS associated with deafness); ECG, electrocardiograms; PCR, polymerase chain reaction; RFLP, restriction fragment length polymorphism.

\section{Competing interests}

The author(s) declare that they have no competing interests.

\section{Authors' contributions}

SZ recruited the patients and family and performed the clinical and genetic studies and data analysis. KY performed genetic and clinical studies and data analysis, interpreted the results, and drafted the manuscript. XR participated in the experimental design, data analysis, interpretation of results, and supervision of the project. PW participated in genetic studies. SZ participated in genetic studies and data analysis. LC assisted with the recruitment of the patients and family and analysis of the clinical data. JY participated in the analysis of the clinical data. JYL participated in data analysis and interpretation of genetic results. ML participated in the experimental design, data analysis, interpretation of results, and supervision of the project. ML also obtained funding and helped draft the manuscript. QKW participated in the experimental design, analysis of genetic data, interpretation of the results, analysis of clinical data, and supervision of the project, obtained funding, drafted the manuscript, and critically revised the Figures, Table and entire manuscript. All authors approved the final manuscript.

\section{Acknowledgements}

We thank the family members for their enthusiastic participation in this study and Amy Slugg Moore at Medical Editing Services, Department of Scientific Publications, Cleveland Clinic for her professional editing of the manuscript. This study was supported by the National Basic Research Program of China (973 Program) 2007CB5I 2000 and 2007 CB5I 2002 (Q.K.W.) and a China Natural Science Function grant 30470982 (M.L), and in part by an AFIC grant from the State of Ohio Wright Center of Innovation and Biomedical Research and Technology Transfer Partnership Award (Q.K.W.) and an NIH grant R0I HL06625I (Q.K.W.). Q.K.W. is an Established Investigator of the American Heart Association (0440I57N).

\section{References}

I. Vincent GM: The molecular genetics of the long QT syndrome: genes causing fainting and sudden death. Annu Rev Med 1998, 49:263-274.

2. Vincent GM: The Long QT and Brugada syndromes: causes of unexpected syncope and sudden cardiac death in children and young adults. Semin Pediatr Neurol 2005, I 2: I 5-24.

3. Chen S, Zhang L, Bryant RM, Vincent GM, Flippin M, Lee JC, Brown E, Zimmerman F, Rozich R, Szafranski P, Oberti C, Sterba R, Marangi $D$, Tchou PJ, Chung MK, Wang Q: KCNQI mutations in patients with a family history of lethal cardiac arrhythmias and sudden death. Clin Genet 2003, 63:273-282.

4. Jervell A, Lange-Nielsen F: Congenital deafmutism, functional heart disease with prolongation of the QT interval, and sudden death. Am Heart J 1957, 54:59-78.

5. Romano C: Congenital cardiac arrhythmia. Lancet 1965, I :658-659.

6. Ward OC: A new familial cardiac syndrome in children. J Ir Med Assoc 1964, 54:103-106.

7. Wang Q, Q C: Cardiovascular disease and congenital defects. Nature Encyclopedia of Life Sciences 2000, 3:646-657.

8. Wang Q, Curran ME, Splawski I, Burn TC, Millholland JM, VanRaay TJ, Shen J, Timothy KW, Vincent GM, de Jager T, Schwartz PJ, Toubin JA, Moss AJ, Atkinson DL, Landes GM, Connors TD, Keating MT: Positional cloning of a novel potassium channel gene: KVLQTI mutations cause cardiac arrhythmias. Nat Genet 1996, I 2:17-23.

9. Curran ME, Splawski I, Timothy KW, Vincent GM, Green ED, Keating MT: A molecular basis for cardiac arrhythmia: HERG mutations cause long QT syndrome. Cell 1995, 80:795-803.

10. Wang Q, Shen J, Li Z, Timothy K, Vincent GM, Priori SG, Schwartz PJ, Keating MT: Cardiac sodium channel mutations in patients with long QT syndrome, an inherited cardiac arrhythmia. Hum Mol Genet 1995, 4:1603-1607.

II. Wang Q, Shen J, Splawski I, Atkinson D, Li Z, Robinson JL, Moss AJ, Towbin JA, Keating MT: SCN5A mutations associated with an inherited cardiac arrhythmia, long QT syndrome. Cell 1995, 80:805-8II.

12. Mohler PJ, Splawski I, Napolitano C, Bottelli G, Sharpe L, Timothy K, Priori SG, Keating MT, Bennett V: A cardiac arrhythmia syndrome caused by loss of ankyrin-B function. Proc Natl Acad Sci U S A 2004, I 01 : $9137-9142$.

13. Schulze-Bahr E, Wang Q, Wedekind H, Haverkamp W, Chen Q, Sun Y, Rubie C, Hordt M, Towbin JA, Borggrefe M, Assmann G, Qu X, Somberg JC, Breithardt G, Oberti C, Funke H: KCNEI mutations cause jervell and Lange-Nielsen syndrome [letter]. Nat Genet 1997, I 7:267-268. 
14. Splawski I, Tristani-Firouzi M, Lehmann MH, Sanguinetti MC, Keating MT: Mutations in the hminK gene cause long QT syndrome and suppress IKs function. Nat Genet I997, I 7:338-340.

15. Abbott GW, Sesti F, Splawski I, Buck ME, Lehmann MH, Timothy KW, Keating MT, Goldstein SA: MiRP I forms IKr potassium channels with HERG and is associated with cardiac arrhythmia. Cell 1999, 97:|75-187.

16. Plaster NM, Tawil R, Tristani-Firouzi M, Canun S, Bendahhou S, Tsunoda A, Donaldson MR, lannaccone ST, Brunt E, Barohn R, Clark J, Deymeer F, George AL Jr., Fish FA, Hahn A, Nitu A, Ozdemir C, Serdaroglu P, Subramony SH, Wolfe G, Fu YH, Ptacek LJ: Mutations in Kir2. I cause the developmental and episodic electrical phenotypes of Andersen's syndrome. Cell 200I, I05:5II-5I9.

17. Splawski I, Timothy KW, Sharpe LM, Decher N, Kumar P, Bloise R, Napolitano C, Schwartz PJ, Joseph RM, Condouris K, Tager-Flusberg H, Priori SG, Sanguinetti MC, Keating MT: Ca(V)I.2 calcium channel dysfunction causes a multisystem disorder including arrhythmia and autism. Cell 2004, I I9:19-3I.

18. Cronk LB, Ye B, Kaku T, Tester DJ, Vatta M, Makielski JC, Ackerman MJ: Novel mechanism for sudden infant death syndrome: Persistent late sodium current secondary to mutations in caveolin-3. Heart Rhythm 2007, 4: I6I-I66.

19. Wang Q, Pyeritz.R.E.: Molecular genetics of cardiovascular disease. In Textbook of Cardiovascular Medicine Ist ed. edition. Edited by: EJ T. New York, NY, Lippincott Williams \& Wilkins; 2000:I-I 2.

20. Neyroud N, Tesson F, Denjoy I, Leibovici M, Donger C, Barhanin J, Faure S, Gary F, Coumel P, Petit C, Schwartz K, Guicheney P: A novel mutation in the potassium channel gene KVLQTI causes the Jervell and Lange-Nielsen cardioauditory syndrome [see comments]. Nat Genet 1997, I 5:186-189.

21. Piippo K, Swan H, Pasternack M, Chapman H, Paavonen K, Viitasalo $\mathrm{M}$, Toivonen $\mathrm{L}$, Kontula $\mathrm{K}$ : A founder mutation of the potassium channel KCNQI in long QT syndrome: implications for estimation of disease prevalence and molecular diagnostics. J Am Coll Cardiol 200I, 37:562-568.

22. Wang Z, Li H, Moss AJ, Robinson J, Zareba W, Knilans T, Bowles NE, Towbin JA: Compound heterozygous mutations in KvLQTI cause Jervell and Lange-Nielsen syndrome. Mol Genet Metab 2002, 75:308-316.

23. Goldenberg I, Moss AJ, Zareba W, McNitt S, Robinson JL, Qi M, Towbin JA, Ackerman MJ, Murphy L: Clinical course and risk stratification of patients affected with the Jervell and Lange-Nielsen syndrome. J Cardiovasc Electrophysiol 2006, I 7: I I6I-I I 68.

24. Schwartz PJ, Spazzolini C, Crotti L, Bathen J, Amlie JP, Timothy K, Shkolnikova M, Berul Cl, Bitner-Glindzicz M, Toivonen L, Horie M, Schulze-Bahr E, Denjoy I: The Jervell and Lange-Nielsen syndrome: natural history, molecular basis, and clinical outcome. Circulation 2006, I I 3:783-790.

25. Chen Q, Zhang D, Gingell RL, Moss AJ, Napolitano C, Priori SG, Schwartz PJ, Kehoe E, Robinson JL, Schulze-Bahr E, Wang Q, Towbin JA: Homozygous deletion in KVLQTI associated with Jervell and Lange-Nielsen syndrome. Circulation 1999, 99: I 344-I 347.

26. Duggal P, Vesely MR, Wattanasirichaigoon D, Villafane J, Kaushik V, Beggs AH: Mutation of the gene for IsK associated with both Jervell and Lange-Nielsen and Romano-Ward forms of LongQT syndrome. Circulation 1998, 97:|42-| 46.

27. Ning L, Moss AJ, Zareba W, Robinson J, Rosero S, Ryan D, Qi M: Novel compound heterozygous mutations in the KCNQ gene associated with autosomal recessive long $\mathrm{QT}$ syndrome (Jervell and Lange-Nielsen syndrome). Ann Noninvasive Electrocardiol 2003, 8:246-250.

28. Sanguinetti MC, Curran ME, Zou A, Shen J, Spector PS, Atkinson DL, Keating MT: Coassembly of K(V)LQTI and minK (IsK) proteins to form cardiac I(Ks) potassium channel [see comments]. Nature 1996, 384:80-83.

29. Liu W, Yang J, Hu D, Kang C, Li C, Zhang S, Li P, Chen Z, Qin X, Ying K, Li Y, Li Y, Li Z, Cheng X, Li L, Qi Y, Chen S, Wang Q: KCNQI and $K C N H 2$ mutations associated with long $Q T$ syndrome in a Chinese population. Hum Mutat 2002, 20:475-476.

30. Chen $Y H, X u$ Sj, Bendahhou S, Wang XL, Wang $Y, X u$ WY, jin HW, Sun H, Su XY, Zhuang QN, Yang YQ, Li YB, Liu Y, Xu HJ, Li XF, Ma $N$, Mou CP, Chen Z, Barhanin J, Huang W: KCNQ I gain-of-function mutation in familial atrial fibrillation. Science 2003, 299:25I-254.

31. HC B: An analysis of the time-relationships of electrocardiograms. Heart 1920, 7:353-370.
32. Schwartz PJ, Moss AJ, Vincent GM, Crampton RS: Diagnostic criteria for the long QT syndrome. An update. Circulation 1993, 88:782-784.

\section{Pre-publication history}

The pre-publication history for this paper can be accessed here:

http://www.biomedcentral.com/1471-2350/9/24/prepub
Publish with Biomed Central and every scientist can read your work free of charge

"BioMed Central will be the most significant development for disseminating the results of biomedical research in our lifetime. "

Sir Paul Nurse, Cancer Research UK

Your research papers will be:

- available free of charge to the entire biomedical community

- peer reviewed and published immediately upon acceptance

- cited in PubMed and archived on PubMed Central

- yours - you keep the copyright

Submit your manuscript here:

http://www.biomedcentral.com/info/publishing_adv.asp
BioMedcentral 